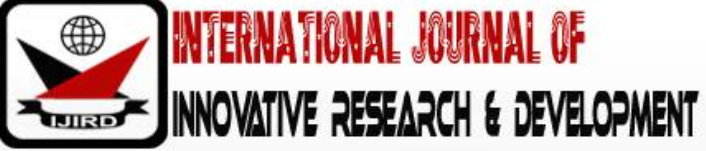

ISSN 2278 - 0211 (Online)

\section{Department of Management Studies Education College of Technology Education, Kumasi University of Education, Winneba, Ghana}

\author{
Ambrose Bangnia \\ Lecturer, Department of Management Studies Education, \\ Kumasi, University of Education, Winneba, Ghana
}

\begin{abstract}
The French like other foreign languages plays a fundamental role as an effective tool in business communication worldwide. Bilingualism or multilingualism is no longer a choice or an option but a must for business growth. Even though English is by far the most studied foreign language at all levels of education and employers across the globe regard it as an important basic skill for businesses, the knowledge of French and other foreign languages is an added advantage for employment in the business sector and that knowledge will make the difference among competitors in the global labour markets. This position paper offers empirical evidence of the positive relation between knowing a foreign language and employment opportunities. The paper examines previous research findings and confirms that there is a positive association between knowing foreign languages and being employed. It also adds to our understanding of the importance of knowing foreign languages particularly French for increasing employment opportunities for professionals at every level of human endeavour. It is obvious that employees' foreign language skills directly and crucially affect inter organisational and intra-organisational communication.
\end{abstract}

Keywords: Business communication, communication, culture, employability, foreign, language, second language

\section{Introduction/ Background of the Study}

Languages by nature are very dynamic and closely intertwined with human culture. Culture is therefore indispensable in the study of language. Throughout history, scholars and linguists have reflected on the importance of language and have given diverse definitions of it. Benjamin Whorf as cited in Algeo (2001) notes that language shapes thoughts and emotions, determining one's perception of reality. John Stuart Mill also cited in Kroon (2017) sees language as the light of the mind Hjelmslev (1968) as cited in Kwofie (2005:6), offers the following definition of language:

Language is the instrument by means of which man fashions his thoughts, feelings, emotions and actions, the instrument by means of which he influences and is influenced by others, the ultimate and deepest foundation of human society.

Moirand (1990:8) presents a similar definition of language:

Le langage est un instrument, un outil. C'est un outil magnifique, mais difficile à manier. Son premier but est de servir, d'être utile. Sans le langage, il n'y a pas de communication entre les êtres. C'est pourquoi nous avons cherché à enseigner, dès le début, le langage comme un moyen d'expression et de communication.

These definitions demonstrate clearly that the principal tool for human communication is language. Language as a term refers to all instruments, means, vehicles or modes of communication. Whether a language is written or not, whether it is African, European, it is primarily spoken. All the languages in the world whether major or minor fulfil this communicative function. Exchange of thoughts, feelings, opinions and values among members of a community is what makes community life meaningful. Language is thus an indispensable means of communication for all societies and upon which their survival depends. Van Berkum (2008) intimated that language is an essential tool that we all use to communicate and exchange ideas with other people. Language therefore is a basic form of communication. Communication therefore cannot be separated from language.

Communication potential is driving dramatic changes in organizations and their environments. As Friedman (2006) points out, globalization is fuelled by technology. But technology alone cannot achieve globalization. What is needed is a sharing of language skills and facilities. Only language can enable individuals and companies as well as countries to communicate. To understand globalization, it is therefore crucial to examine developments in the study of French as a foreign language. It is evident that knowledge in a language is relevant to the understanding and appreciation of the socio-cultural practices of any linguistic community. In this light, knowledge of the codes of behaviour of other people is very necessary if a foreign language student is to effectively and fully communicate in the target language.

It is this linguistic perspective that inspires research in my area as French teacher in the Faculty of Business Education to examine the prospects of employment opportunities through the French language. Language and communication 
dynamics are seen as the driving force in global business. I therefore try to examine the French language specifically as an enabler in communication and globalization.

In social constructivist theory, meaning is seen to arise from social processes constructed through language usage where knowledge is created and shared. As Allen (2005:37) pointed out, "We use language to produce and reproduce knowledge as we enact various roles within various contexts." Knowledge sharing through language is the formal and informal exchanges of ongoing social interaction that mobilizes knowledge that is dispersed around the organization or its stakeholders (Doz, Santos, \& Williamson, 2001; Kalla, 2006). Knowledge sharing through French as a foreign language will create employment opportunities and social capital necessary for thriving concerns. In this regard, we as Ghanaians in general and business professionals in particular in the 21 st Century should be part of this knowledge sharing through the use of the French language. Studies indicate the basic facts about the French language and the prospects of employment opportunities in global business.

\section{Facts about the French Language and the Need to Teach and Learn It in Ghana}

French is among the over 6,000 languages registered around the world (OIF, 2014).

Studies reveal that it is one of the most useful and most studied languages especially in the professional environment as determined by their diffusion around the world (Noack \& Gamio, 2015).

There are an estimated 274 million French speakers worldwide, among them 212 million with a daily use, $54.7 \%$ living in Africa. In terms of ranking, the French is next to English as the ten most widely spoken, studied and the fastest spreading languages today as first and second language users worldwide. $60 \%$ of French speakers are under 30 years old in most of the IOF member countries.

The French is a language for business. The French-speaking countries account for $19 \%$ of world trade in goods exports and imports (Natixis \& OIF, 2014). Today, the importance of the French language in the business world cannot be ignored. It has been adopted by multi-national corporations such as Apple, automobile manufacturers like General Motors as the most effective means of gaining access to global commerce and trade. The knowledge of the French language will not only allow for access to commerce and trade, it also provides an efficient way by which business is conducted. Apart from cultural differences and aside the predominance of English, French serves as an efficient means of communication to conduct business throughout the world. It has also provided an effective tool used to deal with political differences seen as barriers to trade between Francophone and Anglophone countries in particular.

French is among the top three most useful languages for business after English and Mandarin Chinese (which is the world's second-largest economy). It is also the 2nd business language of the European zone after English ahead of German, Russian, Italian and Spanish (Bloomberg, 2011). Bloomberg Rankings first identified the 25 languages with the greatest number of native speakers, and then narrowed the list to 11 that are official languages of G20 countries. This is perhaps the over-riding reason why the French language apart from English has been considered as one of the most influential languages in the business world.

- French is the 3rd most widely used language on the Web with 5\% of Internet pages, after English (45\%) and German ( $7 \%)$ and ahead of Spanish (4.5\%).

- French is an official language in many countries. It is either the official language, or one of the official languages in 32 of the IOF's member states, governments or observers. The Francophone world is spread across the globe: Europe, Africa, and the Americas as well as the Pacific, with Europe and Africa offering the largest concentration of countries where French is recognised as an official language. In 2015, about 40\% of the Francophone population lived in Europe, 35\% in sub-Saharan Africa, 15\% in North Africa and the Middle East, 8\% in the Americas, and 1\% in Asia and Oceania

- French is the second most widely spoken mother tongue (16\%) after German (23\%) and ahead of English (15.9\%), the 2nd most widely spoken foreign language (19\%) after English (41\%) and ahead of German (10\%) and Spanish (7\%) and second most taught foreign language in the European Union. It is also the sixth most spoken language in the world, behind Mandarin Chinese, English, Hindi, Spanish, and Arabic, and is the second most studied language worldwide with about 120 million current learners. Nineteen (19) countries have French as a language of instruction, 13 in Africa at the pre-tertiary level while other countries have French or bilingual studies at the tertiary level of education.

- There are an estimated 900,000 French teachers worldwide.

- Africa is the continent with the largest number of French speakers, with 96.2 million French speakers in the IOF member countries.

- March 20, 1970 saw the birth of an intergovernmental organisation of French-speaking nations, with the creation in Niamey (Niger), of the Agency of Cultural and Technical Cooperation. This organisation adopted a new Charter of Francophonie in 2005 and was renamed the International Organisation of La Francophonie (IOF) as it is still known today.

- As of 2008, the IOF has 84 states and governments (including 23 observers) across five continents with a total of 890 million people, representing $13 \%$ of the world's population and over one-third of the United Nation's member states.

- TV5MONDE, the multilateral French language television channel, has the 3rd largest international television network and is broadcast in 202 countries. TV5MONDE broadcasts French productions 24 hours a day to an audience estimated at over 220 million homes. 
- The IOF has signed cooperation agreements with 31 international and regional organizations including the UNO, the European Union and the African Union. All IOF's member states signed the Convention on the Rights of the Child.

- The Parliamentary Assembly of La Francophonie comprises 78 parliaments or interparliamentary organizations.

- The Academic Agency of La Francophonie federates 781 establishments for further education and research in 94 countries. The International Association of Francophone Mayors represents cities in 48 countries. It comprises cities and city associations from 49 countries.

Sources:

(Ethnologue, 2016)

(https:// www.un.org (2016)

(https:// www.internetworldstats (2016)

(https:// www.un.org 2016).

(https:/ / www.ghanaweb.com/ GhanaHomePage/ features/ Language-barrier-347516).

Today, French maintains a well-deserved place of importance. It is a language of instruction, language of government, and lingua franca of business. It is also among the principal languages of diplomacy and of important international organizations.

Studies indicate clearly that the knowledge of the French language is one of the most important tools available to us since political and economic issues take centre stage at the international level (Overmann, 2011). Therefore, there is a growing need for Ghanaians and more importantly Ghanaian professionals to be competent in foreign languages especially French.

\section{Historical Overview of the French Language in Ghana}

Despite the official status of English (a colonial heritage) as a second language, the teaching and learning of French started as far back as 1879 (Amonoo, 1988). It began at Mfantsipim and Adisadel schools in Cape Coast, when the then colonial school authorities deemed it fit to introduce French as a second foreign language. It eventually spread to other schools in Ghana. The decision to teach and learn French, it must be noted, was as a result of the geographical location of Ghana. The country is bordered by three francophone neighbours namely: Togo in the east, Côte d'Ivoire in the west and Burkina Faso in the north. This strategic geographical position makes it expedient for the teaching and learning of French in Ghana. Consequently, the government of Ghana, with support from the French government has, over the years, put in place various measures to enhance the teaching and learning of French. Those measures resulted in the creation of departments of French in three Colleges of Education (Mount Mary, Wesley and Bagabaga) and tertiary institutions with the aim of increasing the number of trained teachers of French for the basic and secondary schools.

Ghanaians in general and students at all levels of education in particular frequently view the French language as a challenge despite the efforts of the French and Ghana governments, tertiary institutions, organizations and other stakeholders. It is still easily observed that enrolment figures at all levels remain abysmally low. Consequently, there has always been shortage of teachers of French particularly at the secondary level where there are over 800 senior high schools. It was reported in 2008 a shortage of 4000 teachers of French at the secondary level. Only three (3) out of thirtyeight (45) Colleges of Education train teachers of French. It is therefore not surprising that majority of Ghanaian professionals lack the knowledge of the French language. Studies indicate clearly that only one percent of the over 30 million Ghanaians can speak French (OIF, 2018). The tables 1, 2, 3 and 4 below indicate clearly the situation on the ground.

\begin{tabular}{|c|c|}
\hline Category & Number \\
\hline Primary Schools & 18,530 \\
\hline Junior Secondary & 8,850 \\
\hline Senior Secondary & 900 \\
\hline Technical Universities \& Polytechnics (Public) & 10 \\
\hline Colleges of Education & 45 \\
\hline Universities & 31 \\
\hline
\end{tabular}

Table 1: Number of Public/ Private Educational Institutions

Source: Ministry of Education, Accra

\begin{tabular}{|l|l|r|}
\hline Year & BECE & WASSCE \\
\hline 2013 & 155,600 & 32,918 \\
2014 & 171,247 & 19,003 \\
2015 & 180,350 & 19,607 \\
2016 & 192,540 & 21,998 \\
2017 & 199,160 & 22,410 \\
2018 & 212,180 & 25,193 \\
\hline
\end{tabular}

Table 2: Number of Pupils Who Sat For

BECE \& WASSCE (2013 To 2018)

Source: WAEC, 2018, Accra 


\begin{tabular}{|c|c|c|c|c|c|c|c|c|}
\hline College & 2010 & 2011 & 2012 & 2013 & 2014 & 2015 & 2016 & 201 \\
Mt. Mary & 130 & 133 & 123 & 117 & 117 & 119 & 114 & 85 \\
Wesley & 108 & 113 & 120 & 76 & 90 & 84 & 137 & \\
Bagabaga & 35 & 32 & 39 & 45 & 37 & 80 & 76 & \\
Table 3: Number of Teachers Who Graduated from \\
Solleges of Education (2010 - 2018) \\
$\qquad$\begin{tabular}{c|c|c|c|c|c|} 
Year & UEW & KNUST & UCC & UG & Total \\
\hline 2010 & 97 & 70 & 15 & 144 & 326 \\
2011 & 83 & 78 & 16 & 172 & 349 \\
2012 & 93 & 39 & 19 & 138 & 289 \\
2013 & 110 & 113 & 19 & 112 & 354 \\
2014 & 125 & 54 & 17 & 103 & 299 \\
2015 & 98 & 55 & 17 & 161 & 331 \\
2016 & 94 & 70 & 24 & 112 & 300 \\
2017 & 148 & 38 & 35 & 139 & 360 \\
2018 & 177 & 48 & 30 & 125 & 380 \\
\hline
\end{tabular}
\end{tabular}

Table 4: Number of Students Who Graduated with French from

Universities (2001- 2018)

Sources: MIS; KNUST, UG, UEW, UCC, 2018

Ghana as a member state of various international organizations like the African Union (AU), Economic Community of West African States (ECOWAS) and United Nations Organisation (UNO), finds it necessary for the teaching and learning of French in order to foster unity, understanding and enhance the socio-economic and political development and integration of member states. To achieve these goals, all barriers whatsoever should be removed. In ECOWAS in particular and $\mathrm{AU}$ in general, the most lingering and obvious barrier is that of language and that barrier is between the French and English.

Today, efforts are being made to eliminate the language deficiency and maximise the overriding benefits of regional integration. Various tertiary institutions (both public and private) in Ghana particularly the University of Education, Winneba, University of Cape coast, Kwame Nkrumah University of Science and Technology train French teachers for the first and second cycle schools. There are equally Colleges of Education which train teachers to handle the French language at the basic level. Additionally, from 1970-1995, the Government of Ghana with generous support from the French government saw the need to establish regional centres for the teaching of French (CREF). The objective for the creation of these centres was to boost the teaching and learning of French through the organisation of in-service programmes and training workshops. As a result, the National Coordination Office of CREF was set-up in 1997 in conjunction with the Ghana Association of French Teachers (GAFT) for the continuous training of French teachers to upgrade and improve on their professional competencies in the content and methodologies and sharpen their skills in the teaching and learning of French in Ghana. In 2006, a resource and documentation centre known as Francozone was established in Accra, again with massive support from the French government, to enhance research in the various areas of French language teaching and learning in Ghana. The country's interest in the teaching and learning of French and culture culminated in the attainment of membership status in the prestigious International Organisation of the Francophonie (OIF) in 2006, under the leadership of President J. A. Kuffour. As a member of the 56-member organization in 2006, it implies that Ghana:

- Accepts to adhere to the democratic values, cultural diversity through co-operation and the use of the French language.

- Can have easy access to some special priority research and development grants/ funds (e.g. FSP), which, as a non member, she would not enjoy.

- As a member, Ghana also benefited from OIF's assistance to:

- Strengthen the French language skills for Ghanaian diplomats and public officers with international responsibilities and engagements

- Increase the number of teachers of French at the second and tertiary levels

- Develop partnership with the private sector for the teaching of the French language in private companies and associations (OIF, 2006).

Statistics show that enormous efforts have been made by the French government to encourage and ensure that the study of French is beneficial and relevant to Ghanaians. There is therefore the overriding need for Ghanaians to communicate in French, not only because Ghana is surrounded by francophone countries, but also French is the second international language after English.

\section{Francophone and English Vis-À-Vis Anglophone and French}

The Francophone can speak English to an appreciable level because the French-speaking countries have made serious efforts for the teaching and learning of the language in their educational system. From Sixième to the Terminale (a period of seven years) each pupil has a period of four hours of English every week. Obinaju (2004) as cited in Sabo (2010: 8) states that: 
...for the francophone, it will appear from practical experience, more serious efforts have been made to get men and women attached to services especially at the borders, to speak and write English well enough to be at ease with Englishspeaking travelers and customs that they come across.

Unfortunately, the situation in Ghana is the contrary. The level of illiteracy vis-à-vis French in Anglophone countries who are the minority in ECOWAS is very high. A study (Foreman-Peck, 2014) indicates that lack of foreignlanguage proficiency in Britain costs the economy $£ 48$ billion ( $\$ 80$ billion), or $3.5 \%$ of GDP each year. His report finds strong evidence that language skill deficiencies and lack of awareness of the importance of these skills have a significant negative influence on export intensity. His report suggests that because of poor language skills, trade in UK companies in 2006 was lower than it might have been in countries like Brazil, Russia, India, China as well as France, Germany and Japan. Language barriers impact significantly on the performance of businesses. Being able to communicate in the same language as potential trade partners makes a firm more likely to be an exporter. Firms with greater understanding of language and culture are better able to identify and exploit sales opportunities in that market and can achieve higher export sales.

\section{The French Language and Employment Opportunities}

A command of French can be an asset to a career in business or international affairs. An Anglophone bilingual professional can do business with a francophone counterpart with ease. Large and small companies are recognizing that the global market is becoming more and more competitive. A basic competence in the French language, combined with business transactions may open up opportunities in francophone countries.

Learning French as a foreign language opens worlds that are closed to most people. Proficiency in French is a key that unlocks opportunities, not only in business, but in relation to peoples and cultures (Kuupole, 2005).

Studying a foreign language prepares students for dynamic careers in areas such as translation, business, tourism, banking, and education service industries. The demand for employees who speak more than one language is on the rise. According to NIU language experts, the knowledge of a second language will sharpen one's intellect and quality of life. Research indicates that being bilingual can be a significant career advantage. Barbe (2015) stresses the advantages second language learners can realize, both in terms of salary and employability and the sense of adventure. Secondly, the knowledge of other languages raises the awareness that other countries and groups of people do things differently since the language is learned in the context of a different culture (http:/ / newsroom.niu.edu/2015/ 09/16/10-reasons-to-bebilingualKatharinaBarbe).

Since bilinguals have the potential to earn more than monolinguals in their respective professions, the foreign language advantage can translate into more retirement benefits. The Economist found that speaking Spanish is worth an extra $\$ 51,000$ in one's retirement account, while French and German is worth $\$ 77,000$, and $\$ 128,000$ respectively (https:/ / www.economist.com/ blogs/ prospero/ 2014/ 03/ language-study).

Companies today serve increasingly diverse, multilingual populations at home and abroad. Managers know that multilingual consumers are a huge commercial force and represent a significant opportunity for future business. Marketers and advertisers who grasp and activate the multicultural edge will be poised to connect with rising super consumers. Many companies have international offices, sell their products abroad and have production facilities in other countries. These companies want to hire versatile employees who can speak foreign languages and navigate different cultural expectations.

In the United Kingdom, a study conducted in 2014 found that 50\% of British managers considered French to be a valuable asset for their business (British Academy, 2014). It ranked French as the most sought foreign language ahead of German (49\%) and Spanish (44\%). MIT economist Albert Saiz calculated a 2.3\% premium for those who have French as a foreign language in the workplace.

As indicated earlier, French is taught in many universities around the world and it has influences especially in the diplomatic, journalistic, legal and academic worlds (Moreau, 2013). In English-speaking Canada, the United Kingdom and the Republic of Ireland, French retains the privilege of being the first foreign language taught and far ahead of other languages. In the United States, apart from Spanish, French is the most commonly taught foreign language (Brod, 2013).

The future of the French language is often discussed in the news. In 2014, The New York Times documented an increase in the teaching of French in New York, especially in bilingual programmes where only Spanish and Mandarin are now offered more than French. In a study published in March 2014 by Forbes magazine, the investment bank Natixis indicated that French could become the world's most spoken language by 2050. It noted that French is spreading in areas where the population is rapidly increasing, especially in sub-Saharan Africa. With an estimated 270 million speakers across 55 countries, it is clear that Francophones (French speaking people and nations) have an extensive influence worldwide. The same magazine also predicted French to be "the language of the future". The OIL (Organisation Internationale de la Francophonie) predicts that by 2050, an immense 700 million people will be fluent in French. Subsequently, it is no wonder or surprise that the language continues to play a crucial role in international and diplomatic relations.

The figure below indicates OIF's prediction that 700 million people will be fluent in French by the year 2050 . 
Graphique 1 : Répartition des locuteurs par langue

2010

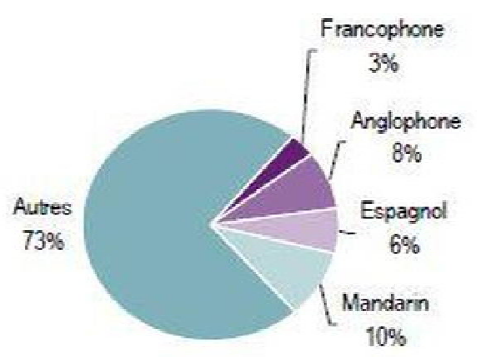

2050

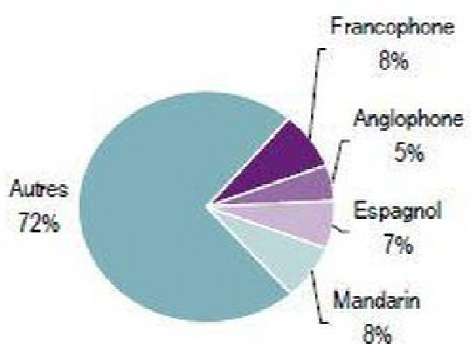

Sources: OIF, divers rapports, Natixis

Figure 1

This prediction is perhaps the over-riding reason as to why French apart from English has been considered as one of the most influential languages in the business world. This is because France and other French-speaking countries conduct or have businesses such as fashion, cosmetics, hair and skincare products, wine, food, film, art, music, banking, hotel industry that are global. Commerce and tourism, art, fashion, wine, have made it a necessity for the French to be bilingual or multilingual. Conventions and shows attract many people from all around the world to France. It is therefore not unusual for the French to commute to Anglophone countries including Ghana to run their business branches there.

\section{Importance of French to Individual Professionals}

With the continuous spread of French as the language of choice throughout the global business community, it is imperative for non-French speakers like Ghana to understand that without the necessary French language skills they risk being left behind in terms of competition.

Being bilingual is eventually becoming the standard for communicating effectively in the world today. Knowing a second language can help advance one career, as many businesses across the globe require professionals with second language (Bhattacharjee, 2012, Beyene, 2012). Additionally, governments and security agencies constantly need people who can speak other languages other than English in order to communicate effectively and with ease. To be a cog in this dynamic world of business, it is important to learn the French language. Hence, learning French is primary to individual success and should be given to anyone wishing to gain access to the corporate world of today business. The knowledge of French also broadens and expands one's education horizons. This is because some graduate and post-graduate programmes have foreign language requirements. For example, in the US, foreign languages are offered as requirement for graduation (ACTFL, 2015).

As the importance of French continues to spread, learning the language appears to be one of the most productive means to meet the demands of a rapidly changing world. In any case, whether the French is one of the most widely spoken languages or not, Ghanaian tertiary students should bear in mind that it is important to learn French as a foreign language which would in the long run be useful in a professional environ (Henry, 2012).

\section{Conclusion, Discussion and Recommendations}

The knowledge of French at a proficient level: being able to understand a wide range of demanding texts and use the language flexibly is associated with an advantage in terms of lucrative employment for Ghanaian professionals. As such, and in accord with the literature reviewed on French as one of the world's most influential languages, being one of the official languages across the globe and reputed to be the most widely used in international communications, after English, this paper makes the case for the potential of employment opportunities for students of the French language in Ghana.

The French language is a crucial tool for the expression of thoughts, culture, feelings and self actualization. In other words, the French like any other language plays a key role as a means of business communication and channels for the expression of knowledge. Hence, the French language, in my view, is a sine qua non condition and an indispensable springboard for personal and national development. Therefore, there should a consistent policy framework for the teaching and learning of the French language in Ghana. As Fishman (1972) pointed out, language policy has to do with political decisions (rules, regulations, guidelines) about the status, use, domains, and territories of language(s) and the rights of speakers of the language(s) concerned. This implies that Government must provide a clear foreign language policy framework for a successful management and implementation. A cursory look at all educational reforms in Ghana from the colonial government under Governor Guggisberg's 1925 Education Ordinance up to the Anamuah-Mensah Review Committee of 2002 shows that the educational policies never provided any clear focus regarding the teaching and learning of the French language. In fact, the educational policies are often ambitiously stated that they tend to fluctuate. Obviously, there are always inconsistencies between policies and practices on the ground (Bamgbose, 1991). It is commonly agreed that any language policy process involves formulation and implementation. However, despite the efforts of various governments regarding the formulation of language policies, we cannot boast of any recognized body for 
monitoring the implementation of these policies in the country. The implementation of the language education policy has never been monitored by the Ministry of Education. This points to the fact that policy makers create safety exits in order to exonerate themselves from any blame emanating from policy failures.

The teaching and learning of French in Ghana are therefore a source of considerable competitive advantage in international socio-economic and political relations. In this regard, special attention needs to be given to the training of teachers of French language. It is important and beneficial to invest heavily in a purposeful promotion of the teaching and learning of the French language in order to bridge the communication gap and open access to other francophone countries and cultures.

It is now possible to conclude this discussion by observing that, through the French language, Ghanaian professionals stand to gain a lot. The knowledge of the French language is a necessity and a hub around which the development of the nation revolves.

In the case of Ghana, the facts of globalization, geographical location and economic development impose on us the need to give priority to French language teaching and learning: a language that is sure to make Ghanaians compete favourably with their Francophone counterparts in the labour markets in the West African sub region in particular and the world at large. The French language should seriously be considered as a language which serves as a medium of communication for daily interactions in every sphere of human endeavour. It is necessary to promote among wide segments of the public and private sectors workforce a proficiency in the French language.

It is gratifying to hear in the March, 2018 edition of la Quinzaine de la Francophonie, the President of the Republic of Ghana, Nana Addo Dankwa Akufo-Addo, affirmed that "We find ourselves in a global climate where the study of [foreign] languages is becoming more and more important ... This is one of the reasons why my government has decided to place particular emphasis on the study of the French language across the educational system"

This was confirmed by Dr. Yaw Osei Adutwum, Deputy Minister in charge of basic and secondary education who reiterated the government's commitment to broaden access to the French language in Ghana and announced the beginning of the "bilingual class" project which is currently being run at the pilot stage in collaboration with the French Embassy.

Quite recently, the Minister for Foreign Affairs and Regional Integration, Hon. Shirley Ayorkor Botchwey said that the decision to obtain French as a second language is a major concern of the Government of Ghana, in line with national priorities. She reiterated plans by government to include the promotion of the learning of French in basic schools and across all other levels of learning, as part of a general reform of Ghana's education sector. She however, regretted the inadequate number of French teachers in the country and limited learning and teaching materials. She therefore encouraged more participation and support in this area

(https:/ / www.ghanaweb.com/ GhanaHomePage/ NewsArchive/ Ghana-committed-to-the-acquisition-of-French-as-asecond-language-Foreign-Minister-731889). Fortunately, a new curriculum has been implemented with the introduction of French at the primary level which will take effect this academic year in September 2019. We hope that this time round the implementation of the new curriculum with the inclusion of French should be sustained to enable more start learning the language at the basic level.

\section{References}

i. Algeo, J. (2001), A Notable Theosophist: Benjamin Lee Whorf, Quest 89.4, pp 148, 149.

ii. Allen, B. J. (2005). "Social constructionism". In S. May \& D. K. Mumby (Eds.), Engaging organizational communication theory and research (pp. 35-54). Thousand Oaks, CA: Sage.

iii. America's Foreign Language Deficit. (2012, August 27). Forbes. Retrieved from http:/ / www.forbes.com

iv. American Council on the Teaching of Foreign Languages (ACTFL). Foreign Language Enrolments in k-12 Public

Schools. Retrieved October 17, 2015

v. Amonoo, R. F. (1988), The GAFT in its early years. Accra, Black Mask Limited.

vi. Bamgbose, A. (1991). Language and the nation. Edinburgh: Edinburgh University Press.

vii. Barbe, K. (2015). 10 reasons to be bilingual. NIU Education. Retrieved from http:/ / newsroom.niu.edu/ 2015/ 09/ 16/ 10-reasons-to-be-bilingualKatharinaBarbe).

viii. Beyene, S. (2012). Language skills: way to get a job? The Guardian. Retrieved from http:/ / www.guardian.co.uk

ix. Bhattacharjee, Y. (2012), Why bilinguals are Smarter. The New York Times. Retrieved from http:/ / www.newtimes.com

x. Bloomberg Rankings (2011). Languages most useful other than English for conducting business around the world. Retrieved from http:/ / www.aatfri.com/ pdf\%20files/ Bloomberg\%20Rankings_Business\%20languages.pdf

xi. Brod, R. I. (2013) "Enrollments in Languages Other Than English in United States Institutions of Higher Education, Fall 2013" Retrieved May 11, 2017.

xii. Doz, Y. L., Santos, J., \& Williamson, P. (2001). From global to metanational. Boston, MA: Harvard Business School Press.

xiii. Fishman, J. A. (1972). Sociology of Language: An interdisciplinary social science approach to language in Society: Stanford, Stanford University Press

xiv. Foreman-Peck, J. (2014). The costs to the UK of language deficiencies as a barrier to UK trade performance. Cardiff Business School

xv. Friedman, T. L. (2006). Baron's Dictionary of Business Terms $4^{\text {th }}$ Edition, New York, Baron's Educational Series French Ministry of Foreign and European Affairs (2014), "Le français, une langue mondiale". Retrieved 2017-0315. 
xvi. Henry, J. (2012), Foreign languages to be compulsory from age seven. The Telegraph. Retrieved from http:/ / www.telegraph.co.uk

xvii. Kalla, H. K. (2006). Integrated communications in the multinational corporation Helsinki School of Economics Publications A-280.

xviii. Kroon, F. (2017), "Mill's Philosophy of Language”, in Macleod and Miller 2017: 207-21.

xix. Kwofie, E. N. (2005), “Language: The Master Key to the Expression of Knowledge”: In Kuupole, D. D. (ed) (2005) Use and Acquisition of Language and Culture: Effects on Human Society. Takoradi, St Francis, P.6

xx. Moirand, S. (1990), Enseigner à communiquer en langue étrangère. Paris, Hachette Moreau, R. (2013), the Value of Foreign Languages in Business Communication, MBA Student Scholarship. Paper16. http:/ / scholarsarchive.jwu.edu/ mba student/ 16

xxi. Noack, R. and Gamio, L. The world's languages, in 7 maps and charts, The Washington Post, April 2015 (Retrieved June 2015).

xxii. OIF (2014). The French language worldwide report.

xxiii. Overmann, M. (2011). President Obama on the importance of foreign language. Retrieved from http:/ / www.alliance-exchange.org/ policy-monitor/ 08/ 22/ 2011/

xxiv. Thill, J. (2001). Communication challenges in today's workplace: excellence in business communication 6th Edition. New York: Pearson Prentice Hall.

xxv. Thill, J. (2005). Excellence in Business Communication 6th Edition. New York: Pearson Prentice Hall.

xxvi. Sabo, D. E. (2010), "The role of French language in the economic and political integration of ECOWAS" Applied Social Dimensions of Language Use and Teaching in West Africa, University of cape Coast, The University Press.

xxvii. Schutzler, M. (2011). Language Learning Helps Businesses Compete Globally. Forbes.Com, 18.

xxviii. Valantin, C. (2007). La Francophonie dans le Monde 2006-2007, Nathan. Accessed 5 May 2011.

xxix. Van Berkum, J. (2008). Understanding sentences in context. Association for Psychological Science, 17 (6), 376-380.

xxx. Weber, G. (1997), The World's 10 most influential Languages

xxxi. (https:/ / www.un.org (2016)

xxxii. (https:// www.internetworldstats (2016)

xxxiii. (https:// www.un.org 2016).

xxxiv. (https:// www.ghanaweb.com/ GhanaHomePage/ features/ Language-barrier-347516

xxxv. http:// www.aatfri.com/pdf\%20files/_Bloomberg\%20Rankings_Business\%20languages.pdf

xxxvi. http:/ / abcnews.go.com/ business/ t/ blogEntry?id=14427844

xxxvii. https:/ / www.economist.com/ blogs/ prospero/ 2014/ 03/language-study

xxxviii. http:// www.ehow.com/about 6721744 languageeffectivecommunication.html\#ixzz2J1ZLb1A3

xxxix. https:/ / www.en.wikipedia.org/ wiki/ ListoomostcommonlearnedforeignlanguagesintheUniteStates

xl. http:/ / www.forbes.com/ sites/ pascalemmanuelgobry/ 2014/ 03/ 21/ want-to-know-the-language-of-the-futurethe-data-suggests-it-could-be-french/

xli. http:// www.frenchlanguagaguide.com/ French/ Facts/ History

xlii. https:// managementstudyguide.com/ portal

xliii. https:/ / www.mosalingua.com/ en/ most-widely-spoken-languages/ ethnologie (2015)

xliv. https:/ / newsroom.niu.edu/ 2015/ 09/ 16/ 10-reasons-to-be-bilingual/

xlv. https:/ / www.newsroom.niu.edu/ 2015/ 09/ 16/ 10-reasons-to-be-bilingual/

xlvi. "Number of Internet Users by Language", Internet World Stats, Miniwatts Marketing Group, 30 June 2016, accessed 15 November 2016.

xlvii. https:// www.thebritishacademy.ac.uk/ ./ 2.\%20SME\%20Language\%20Surv 